\title{
BACTERIOLOGICAL SURVEY OF SEA-WATER FROM THE COAST OF MADRAS CITY (BAY OF BENGAL)*
}

\author{
By N. K. Velankar, B.Sc. (Hons.) \\ (Central Marine Fisheries Research Station, Mandapain, S. India) \\ Received February 13, 1950 \\ (Communicated by Dr. H. Srinivasa Rao)
}

BACTERIA are widely distributed in the marine environment. They infiuence the chemical and biological conditions in the sea. Probably there are as many, or even more, genera of bacteria present in the sea as in the terrestrial environment. Recent work on marine bacteriology lays increasing emphasis on the chemical activities of the bacteria. Bacterial degradation of organic matter into inorganic salts which support plant life is an essential step in the maintenance of the fertility of the ocean. The interconversion of the salts of nitrogen, the transformation of the compounds of phosphorus and sulphur, the breakdown of cellulose, chitin, etc., are processes more or less influenced by microbial action (Waksman, et al., $1933 a, 1933 b, 1933 c$; Hock, 1940; Brand, et al., 1937-42). The role of marine bacteria in the formation of petroleum, which occurs in ancient marine sediments, may prove to be significant (Zobell, $1946 b, 1947 a, 1947 b$ ). The dissolved organic matter in the sea, which is otherwise unavailable, is utilised by the bacteria for the synthesis of their cells, which again provide particulate food material for certain marine animals (Zobell and Landon, 1937). The role of marine bacteria in the spoilage of fish and other marine food products is also of practical importance.

A large volume of work has been done by marine bacteriologists abroad, particularly in the U.S.A. and in the U.S.S.R.; but there is paucity of data for tropical waters. The influence of bacterial activity on the fertility of the sea which is particularly low in the tropical regions, is of fundamental importance. A survey of the occurrence, distribution and nature of the bacteria responsible for the different biochemical processes is essential for understanding their relative influences on the fertility of the sea. The present investigations are in relation to these aspects, i.e., (1) seasonal variation in the density of the bacterial population of surface sea water, (2) relative abundance of bacteria in (i) sea water and (ii) in association

* Published with the kind permission of the Chief Research Officer, Central Marine Fisheries Research Station, Mandapam.

80 
with plankton, (3) qualitative and quantitative survey of the groups of marine bacteria of biochemical significance.

Procedure.-Bacterial populations were evaluated using the plating procedure. Surface sea water samples were collected three miles off the shore (Madras Marina) in sterile glass bottles and plated out immediately upon arrival at the laboratory (about one hour). Plankton samples were obtained at the same time, hauling nets approximately equal distances during all the collections; these samples were placed in sterile glass bottles for transport to the laboratory. Sea water agar (Medium 2216, Zobell, 1946 a) was used as the plating medium. Sea water was plated in 1 c.c., and 1 in 10 dilution duplicates. Plankton samples were plated in 1 in 100 and 1 in 1000 dilution duplicates. Filtered and autoclaved sea water was used for the dilution blanks. The colonies present after 48 hours' incubation at $25^{\circ} \mathrm{C}$. were counted, using a magnifying glass. It is possible that organisms which grow very slowly will be excluded by this procedure, but longer periods of incubation cause inaccuracy in counting due to the presence of colonies of spreading nature. Workers abroad have used lower temperatures and longer periods of incubation, but it may be noted that their studies were generally restricted to relatively colder regions.

\section{Physiological Groups of Marine Bacteria}

Procedure.-Samples of sea water and plankton were inoculated in 1 c.c., $0 \cdot 1$ c.c., 0.01 c.c. lots into appropriate selective media. "Aged" sea water (Zobell, 1946 a) was used for the preparation of the media. This procedure, besides the qualitative demonstration of the active bacteria, also indicates the order of numerical magnitude of their occurrence.

Nitrate reducers were present in large numbers throughout the period of investigation.

True denitrifiers, i.e., bacteria which liberate free nitrogen from nitrogenous salts, were absent.

Bacteria capable of growing in sea water media containing carbohydrates, but free from any added nitrogen compounds, were usually found in 10 c.c. samples of sea water.

Nitrifying bacteria.-Samples of sea water failed to give a positive nitrite reaction during the period of incubation (eight weeks). Plankton samples, when inoculated into ammonium sulphate medium, always produced nitrite within one to two weeks' incubation at room temperature. Bacteria capable of oxidising "ammonium" to "nitrite" appear to be present constantly in association with plankton. In view of the possibility 
Density of physiological groups of bacteria during different seasons

\begin{tabular}{|c|c|c|c|}
\hline Period & $\begin{array}{l}\text { Nitrate Reducers } \\
\text { per c.c. of } \\
\text { sea water }\end{array}$ & $\begin{array}{c}\text { Nitrogen } \\
\text { fixers of sea } \\
\text { water per } 10 \mathrm{c}, \mathrm{c} .\end{array}$ & $\begin{array}{l}\text { Denitrifiers per } \\
10 \text { c.c. of } \\
\text { sea water }\end{array}$ \\
\hline July 1948-Nov. 1948 & 100 to 1,000 & 1 to 10 & nil \\
\hline Dec. 1948-March 1949 & over 1,000 & 1 to 10 & nil \\
\hline April 1949-July 1949 & 100 to 1,000 & 1 to 10 & nil \\
\hline \multirow{2}{*}{ Period } & \multicolumn{2}{|c|}{ Nitrifying bacteria per c.c. of } & \multirow{2}{*}{$\begin{array}{l}\text { Urea fermenters } \\
\text { per c.c. of } \\
\text { sea water }\end{array}$} \\
\hline & Sea water & Plankton . & \\
\hline July 1948-N ov. 1948 & nil & 1 to 10 & 1 to 10 \\
\hline Dec. 1948-March 1949 & nil & 10 to 100 & 10 to 100 \\
\hline April 1949-July 1949 & nil & 1 to 10 & l to 10 \\
\hline
\end{tabular}

\begin{tabular}{l|c|c}
\hline \multirow{2}{*}{ Period } & \multicolumn{2}{|c}{ Cellulose fermenters per c.c. of } \\
\cline { 2 - 3 } & Sea water & Plankton \\
\hline July 1948-Nov. 1948 & nil & 1 to 10 \\
Dec. 1948-March 1949 & nil & 1 to 10 \\
April 1949-July 1949 & nil & 1 to 10 \\
\hline
\end{tabular}

of plankton being an important site for the activity of marine bacteria, this nitrification by bacteria associated with plankton merits a detailed investigation (Carey, 1938).

There appears to be no seasonal qualitative change in the biochemically active bacterial flora, the changes observed being of a quantitative nature only.

Study of the density of the bacterial population of surface sea water off Madras during the period April 1948 to July 1949 was carried out. During April 1948 to July 1948 bacteria averaged 400 per c.c.; August 1948 to November 1948, 600 per c.c.; during December 1948 to March 1949 the average was over 1,000 per c.c. From the middle of March 1949 a sharp fall was noted. The level of bacterial population in April, May 
Bacteriological Survey of Sea-Water from Coast of Madras City 83

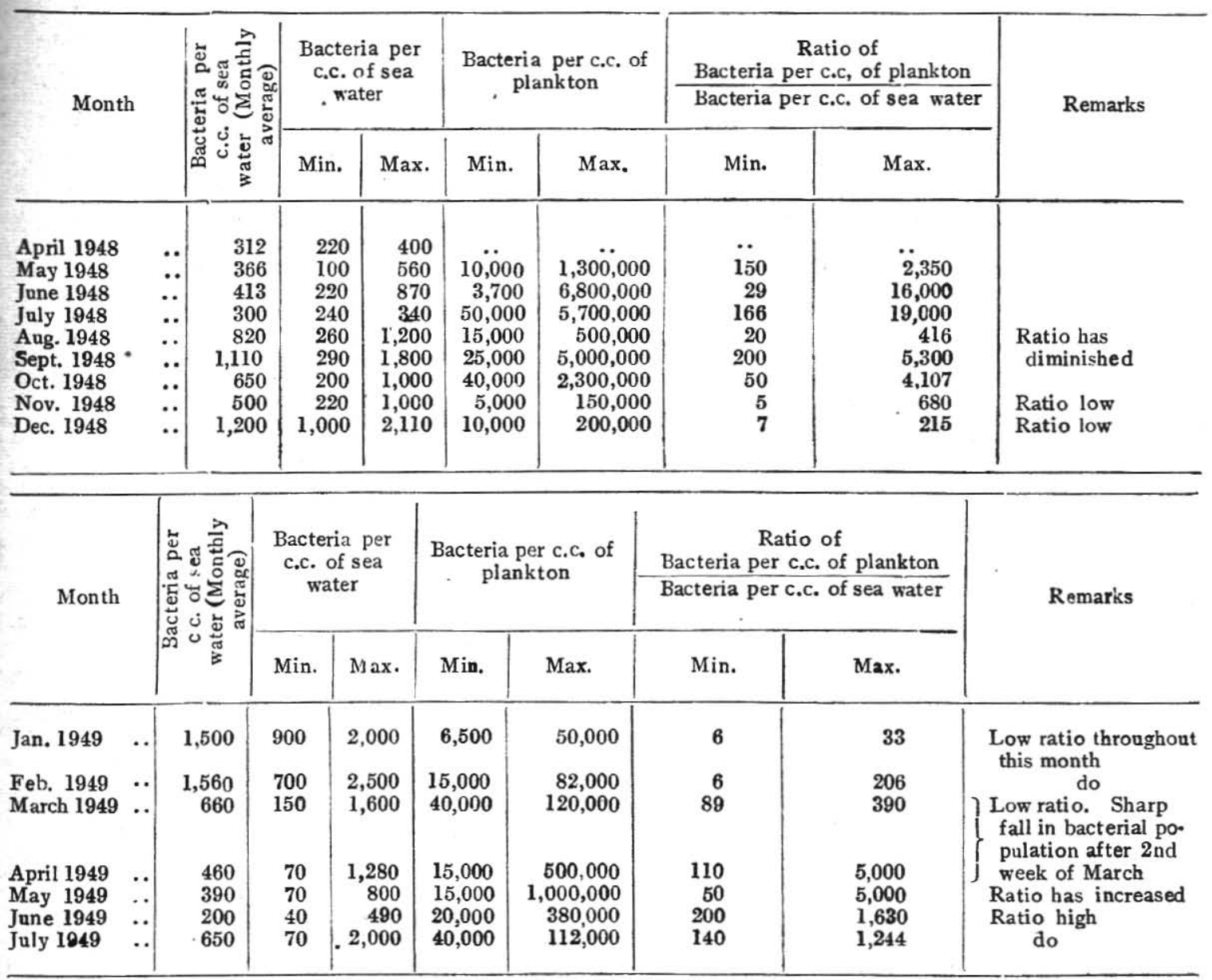

and June 1949 was the same as observed for the previous year, indicating the possibility of the variation being seasonal. Observations over a longer period are necessary.

During April 1948 to November 1948 a close parallel between the abundance of bacteria and phytoplankton is observed (Graph I). This parallel does not continue in the next few months. The latter period was characterised by the prevalence of continuous " disturbed" conditions, which might account for the discontinuity (see the following).

The bacteria in the plankton tow are thousands of times higher than in the sea water, the ratio fluctuating widely from 5:1 to $19,000: 1$. The ratio tends to be low during periods of stormy weather. Higher bacterial counts in plankton samples are usually obtained when the plankton 


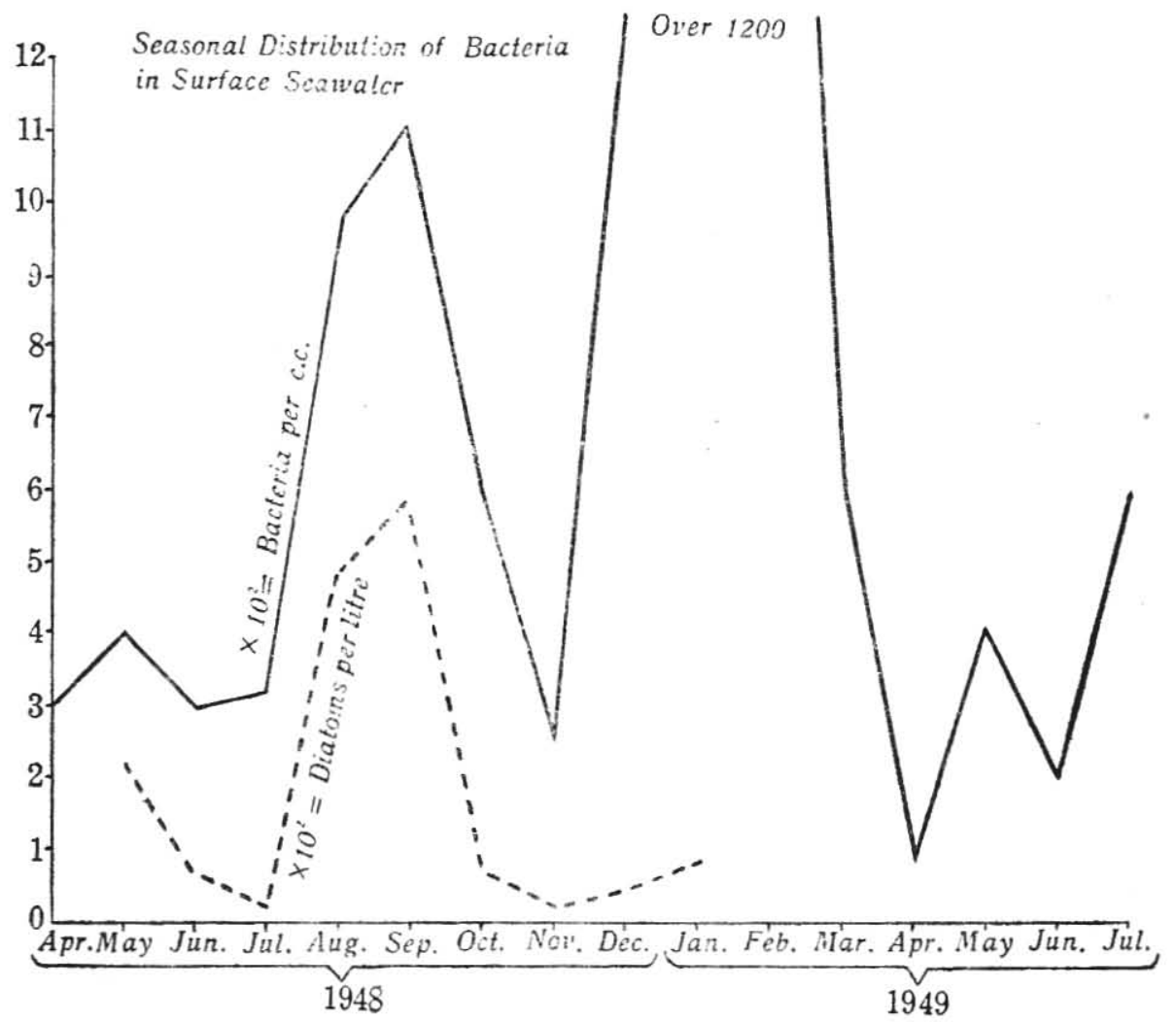

GRAPH I

consists predominantly of phytoplankton and lower counts when zooplankton predominates. The nature of the influence of the plankton on bacterial population is not clear, though it is generally believed that the phytoplankton secretes nutrients for the bacteria, while the zooplankton may diminish the bacterial population by grazing.

During and immediately following stormy weather the bacterial counts were always high. This may be ascribed to the upwelling of particulate organic matter by the disturbed conditions. The numerical magnitude of the bacterial population appears to bear a relation to the salinity of the sea water (Graph II). The curves, showing the monthly average density of bacterial population and the monthly average salinity do not show a strictly inverse relation, but the tendency of the bacterial population to rise as the salinity falls and to diminish as the salinity approaches the normal is obvious. It is unlikely, however, that the salinity changes as such would influence the bacterial population, since marine bacteria are known to 


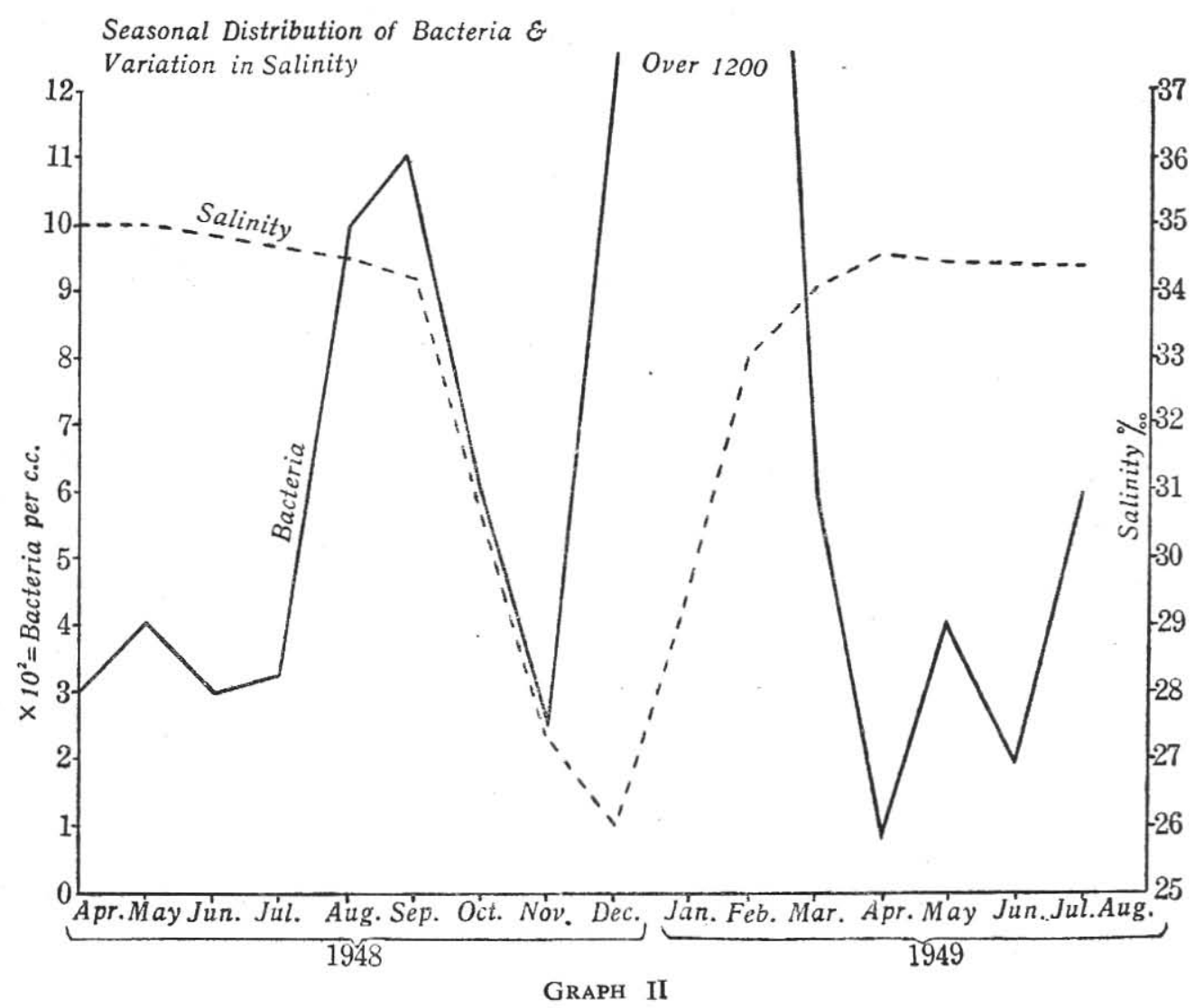

tolerate the salinity ranges in question. Regarding the fall in salinity as an index of the influx of masses of fresh water carrying organic matter might provide an explanation for the rise in bacterial population.

During the four months November 1948 to February 1949 comparatively lower values for the concentration of nitrate in the sea water were reported (private communication by Mr. R. Jayaraman, Central Marine Fisheries Research Station, Mandapam). The bacterial population during this period was the maximum observed. The lowering in the nitrate level may have a relation to the high bacterial population, since many of the bacteria are nitrate reducers.

My thanks are due to Dr. (Mrs.) F. Thivy, Central Marine Fisheries Research Station, Mandapam, for kindly making the phytoplankton counts, 


\section{REFERENCES}

1. Brand, Theodor von and Rakestraw, Norris, W.

2. Carey', Cornelia, L.

3. Hock, C. W.

4. Waksman, Selman, A. et al.

5. Zobell, C. E. and Landon, W. A.

6. Zobell, C. E.
Biol. Bull., 1937-42, 72, 77, 79, 81 and 83.

.. "The occurrence and distribution of nitrifying bacteria in the sea,"Journ. Mar. Res., 1938, 1, 291.

. "Decomposition of chitin by marine bacteria," Biol. Bull., 1940, 79, 199.

.. "Bacteriological examination of sea water and marine bottoms," ibid., 1933a, 64, 183.

.. "Decomposition of marine plant and animal residues by bacteria," ibid., $1933 b, 64,57$.

.. "Bacteria concerned in the cycle of nitrogen in the sea," ibid., 1933c, 65, 137.

.. "Bacterial nutrition of the California sea mussel" Proc.Soc. Exp. Biol. \& Med., 1937, 36, 607.

.. "Marine Microbiology," (A monograph on hydrobacteriology), Published by the Chronica Botanica Company, Waltham, Mass., U. S. A., $1946 a$.

.. "Function of bacteria in the formation and accumulation of petroleum," Oil Weekly, $1946 b, 120$ (12), 30.

.. "Microbial transportation of molecular hydrogen in marine sediments," Bull. Amer. Assm. Petrol. Geol., 1947a, 31, 1709, 51.

.. "Bacterial release of oil from oil-bearing materials," World Oil, 1947b, 126 (13), $36 ; 127$ (1), 35. 


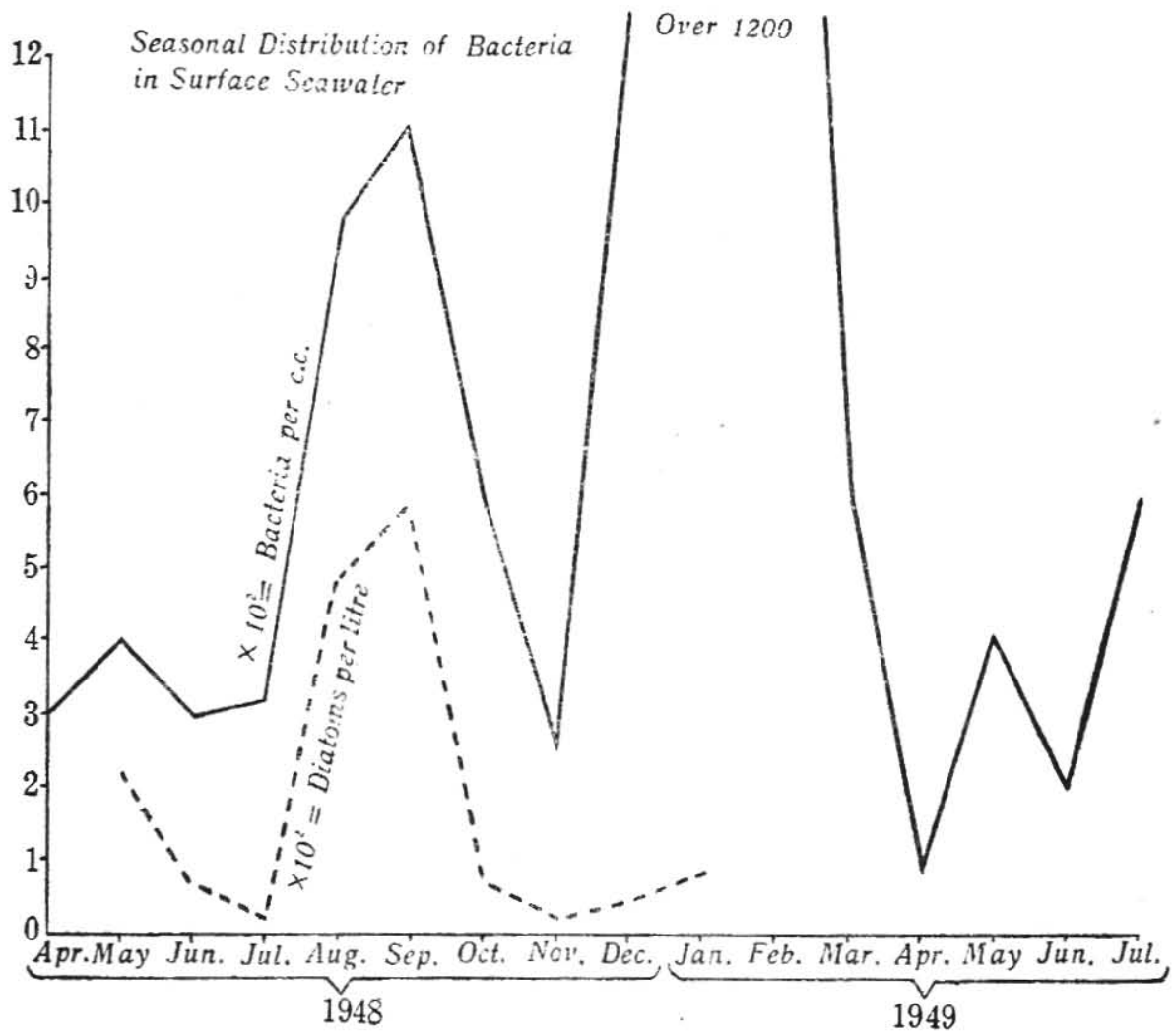

GRAPH I

consists predominantly of phytoplankton and lower counts when zooplankton predominates. The nature of the influence of the plankton on bacterial population is not clear, though it is generally believed that the phytoplankton secretes nutrients for the bacteria, while the zooplankton may diminish the bacterial population by grazing.

During and immediately following stormy weather the bacterial counts were always high. This may be ascribed to the upwelling of particulate organic matter by the disturbed conditions. The numerical magnitude of the bacterial population appears to bear a relation to the salinity of the sea water (Graph II). The curves, showing the monthly average density of bacterial population and the monthly average salinity do not show a strictly inverse relation, but the tendency of the bacterial population to rise as the salinity falls and to diminish as the salinity approaches the normal is obvious. It is unlikely, however, that the salinity changes as such would influence the bacterial population, since marine bacteria are known to 